\title{
EFFECT OF PROBIOTIC BACTERIA INCLUSION IN CREAM ON BLOOD PLASMA LIPIDS
}

\author{
Wafaa B. Elsabie ${ }^{1}$ and Samia I. Harby ${ }^{2}$ \\ 1- Dairy Chemistry, Department, Animal Production, Research Institute, 2- Dairy \\ Microbiology Department, Animal Production, Research
}

\section{SUMMARY}

Thirty adult male Albino rats were used in this study, divided equally into 6 groups. The first group was fed on basal ration (as a control). The second group was fed on basal ration with cream. Each of the remaining 4 groups was fed on basal ration and the prepared probiotic-cream fermented with Lactobacillus acidophilus, Bifidobacterium bifidium, Lactobacillus casei and the mixture of all at a ratio of 1:1:1. Blood samples were taken at 15, 30, and 45 days of feeding intervals for the determination of blood lipids content. Fecal samples were collected on 15, 30 and 45 days post feeding for microbiological analyses.

Total cholesterol, low density lipoprotein ( $L D L)$ cholesterol, total lipids and triglycerides were significantly increased for the non-probiotic cream compared to control group. In probiotic cream treatments, all of the previously mentioned traits were significantly reduced with variable magnitudes compared with non-probiotic cream, where L. casei and the mixture of the three strains were superior in their effect. High density lipoprotein (HDL) cholesterol was significantly increased in each of the probiotic cream treatments compared to the non-probiotic cream with variable differences. Values of the studied traits were relatively increased as the feeding intervals prolonged with some noticeable quantified differences within first and second durations. Post 45 days feeding, inclusion L. casei or mixture of the three probiotic strains to cream obviously reduced blood plasma lipids in rats, followed by B. bifidum and L. acidophilus bacteria.

Microbial fecal analysis indicated significant drastic decreases in the population of staphylococci and total coliforms for the probiotic cream treatments compared to the non-probiotic cream and the control groups as well, where the highest effect was recorded for L. casei and the mixture of the three probiotic strains. Such pathogenic microorganisms decreased as feeding intervals increased for the probiotic cream treatments. It could be concluded that inclusion probiotic bacteria in the cream (especially L. casei or mixture of three strains as a ratio 1:1:1) alleviate the harmful effects results in fed non-probiotic cream alone and create healthy beneficial effect.

Keywords: Probiotic cream, total cholesterol, LDL, total lipids and triglycerides

\section{INTRODUCTION}

Probiotics are dietary supplements containing potentially beneficial bacteria which are successfully used for creating health benefits. Lactic acid bacteria (LAB) are the most common type of probiotic bacteria. Among the probiotic popular Issued by The Egyptian Society of Animal Production 
potential medicinal functions in dietary healthy food and dairy products are:Maintaining normal intestinal microflora with a self reestablishing probiotic bacteria (Fooks et al., 1999). Probiotic bacterial cultures are claims to strength the immunity system to combat allergies, excessive alcohol intake, stress, exposure to toxic substances and other diseases (Sanders.,2000 and Nichols.,2007) reduction of lactose intolerant (Jiang et al., 1996) lowering blood pressure (Sanders, 2000) prevention of acute \& travelers diarrhea (Reid, 2003) reduce serum cholesterol (Kailasapathy and Rybka ., 1997) prevent colon cancer by exerting anti-carcinogenic effect (Coakley et al.,2003) eliminate residual effect of antibiotic treatments Hiliobacter pylori (Kocian, 1994) reduce inflammation due to the regulation of cytokine functions (Reid et al., 2003) improve mineral absorption (Famularo et al., 2005) prevent harmful bacterial growth under stress (Hitti, 2006) improve some symptoms of irritable bowel syndrome in women in a recent study (Whorwell et al., 2006) and ulcerative colitis (Guyonnet et al., 2007). All of such effect can be only attributed to the strains tested not to the species, nor to the whole group of LAB or other properties.

Cholesterol is found in lipid fractions in 3 forms (Lacroix et al., 1973): free in the fat, bound to the lipoprotein of the fat globules, and as the cholesterol (Jenness and Patton, 1959). However at least $95 \%$ of the cholesterol in dairy products is in the first two forms (Deman, 1964).

Animal studies have demonstrated the efficiency of a range of LAB to be able to lower serum cholesterol levels, presumably by breaking down bile in the gut, thus inhibiting its re-absorption (which enters the blood as cholesterol). Some, but not all human trials have shown that dairy foods fermented with specific LAB can produce modest reductions in total LDL cholesterol levels in those with normal levels to begin with. However, reduces the incidence of cardiovascular disease. Modification of diets, such as supplementation of diet with fermented dairy products or lactic acid bacteria-containing dairy products is one way that serum cholesterol may be reduced

High fat milk is commonly used in many milk products which can elevate cholesterol content in blood plasma, causing cardiovascular heart disease (CVD). So, the target of this research is to find out the impact of some probiotic bacteria as $L$. acedophilus, L. casei and B. bifidum and their mixture on total cholesterol, HDL cholesterol, LDL cholesterol, total lipid and triglycerides content in rats blood plasma fed with such probitic supplemented cream.

\section{MATERIALS AND METHODS}

Experiments were conducted for the sake of finding the impact of probiotic supplements of cream (35\% fat content) constituents using blood serum of adult male albino rats.

\section{Preparation of cream and probiotic cream:}

Buffalo milk was separated in skim milk and cream, cream was diluted by skim milk to reach $35 \%$ fat. Such prepared cream was heated at $72{ }^{\circ} \mathrm{C}$ for $15 \mathrm{sec}$ then divided into 5 equal portions and cooled to the appropriate incubation temperature. The $1^{\text {st }}$ portion was cooled to $30^{\circ} \mathrm{C}$ for Lactobacillus casei., $2^{\text {nd }}$ portion was cooled to $37^{\circ} \mathrm{C}$ for Bifidobacterium bifidum and the $3^{\text {rd }}$ portion was cooled to $37^{\circ} \mathrm{C}$ for Lactobacillus acidophilus. Whereas, the $4^{\text {th }}$ portion was cooled to $35^{\circ} \mathrm{C}$ for the mixture of the three previously mentioned strains as ratio of $1: 1: 1$. Plus the non 
probiotic cream. The first three portions of the prepared cream were inoculated with each of the previously mentioned strains at $3 \%$ as a starter. This ratio was a result of pilot sensory evaluation which proved that using probiotic strains inoculation level of $3 \%$ for sour cream (35\% fat) was more acceptable than 1.5 and $5 \%$ levels. Such cream patches were stored in the refrigerator freezer at $-18 \pm 2^{\circ} \mathrm{C}$ in sealed tubes for daily feeding. Before feeding, rats sample were kept in the refrigerator for 12 hours at $7 \pm 1^{\circ} \mathrm{C}$. The microbiological media used in this study were ready made and supplied from Oxoid Division, Oxoid Ltd, London.

\section{Experimental animals and diets:}

In vitro trials, using 30 adult male albino rats (120-150 BW) were obtained from Faculty of Pharmacology, Cairo University. Animals were transported to laboratory of Plant Protection Research Institute (room temperature $22 \pm 2^{\circ} \mathrm{C}$ ), and caged individually for two weeks acclimatization and fed on a basal ration and water. Rats were divided into 6 groups. The ${ }^{\text {st }}$ group served as the control (fed a basal ration), $2^{\text {nd }}$ was fed on basal ration+ cream (non probiotic cream), the $3^{\text {rd }}$ was fed on basal ration +cream with $L$. acidophilus, the $4^{\text {th }}$ fed basal ration+ cream with B. bifidum, and finally the $5^{\text {th }}$ was fed basal ration + cream with $L$. casei and last one fed basal ration+mixture of the 3 previously mentioned probiotic bacterial strains as ratio $1: 1: 1$

Rats were daily fed ad libitum according to the above assigned presented treatments, where the amount of cream was $0.5 / 100 \mathrm{~g} \mathrm{BW}$. The experimental duration was 45 days.

\section{Blood samples and determination of plasma lipids}

Blood samples of rates were taken after 15, 30 and 45 days of feeding from eyes vein in heparinized tubes to determine blood plasma lipids content. Total cholesterol was determined enzymatically using commercially kits (Stanbio No 1010). Triglycerides were analyzed according to Stanbio kits No 2100. The HDL cholesterol was analyzed according to Stanbio kits No 0599, whereas, LDL cholesterol determined according to polyvinyl sulfate method using Qumica Clinica Applicada S.A.P.O. Box 20-E43870 AMPOSTA/Spain.. Total lipids were determined colorimetrically where lipids react with sulfuric phosphoric acids and vanillin to form a pink colored complex according to Zollner and Kirsch (1962).

\section{Samples and microbiological analysis:}

Samples were taken from fresh prepared probiotic cream and non- probiotic cream and after 15,30 and 45 days of storage on $-18 \pm 2{ }^{\circ} \mathrm{C}$ to count the survival of lactic acid bacteria $\left(10^{7}\right)$ in probiotic cream and total bacterial count $\left(10^{2}\right)$ in the nonprobiotic cream.

The microbiological media used in this study were ready made from Oxoid Division, Oxoid Ltd London. Microbiological analysis was conducted for L. casei according to Vinderola and Reinheimer (2000). Whereas, B. bifidum enumerated according to Dave and Shah (1996), using the modified MRS agar supplemented with $0.05 \%$ L. cysteine-HCL. The antibiotic mixture NPNL (Neomycin sulphate, paramonycin sulphate, Nalidixic acid and lithium chloride) as a selective agent was sterilized by filtration through $0.22 \mu \mathrm{m}$ Millipore filter (Gellman Sci., England) then added to the medium at a rate of $50 \mathrm{ml} / \mathrm{L}$ medium just before pouring the plates.. 
L.cystein-HCL solution sterilized by filtration ( $0.05 \%$ final concentration) was also added. The plates were anaerobically incubated at $37^{\circ} \mathrm{C}$ for $48 \mathrm{hrs}$, using anaerogen sachets. L. acidophilus count was determined according to Dave and Shah (1996) using MRS-Salccin agar. The plates were incubated at $37^{\circ} \mathrm{C}$ for $48 \mathrm{hrs}$. Total bacterial count was determined as described by the American Public Health Association APHA (1992).

\section{Stool samples and fecal analysis:}

Fecal samples were collected at 15, 30 and 45 post feeding duration days in separate sterile tubes for microbiological analyses, and then placed into anaerobic jars. Microbiological analysis was conducted for staphylococci and coliform the group within an hour after collection. Coliform was determined according to Marshal (1992) and Staphylococci according to Baird-Parker (1962)

\section{Statistical Analysis}

Data were statistically analyzed using General Linear Model procedure of SAS ${ }^{\circledR}$ Program (1996) according to the following model:

$$
\mathrm{Y}_{\mathrm{ijk} \ldots}=\mu+\mathrm{T}_{\mathrm{i}}+\mathrm{FD}_{\mathrm{j}}+\mathrm{TFD}_{\mathrm{ij}}+\mathrm{e}_{\mathrm{ijk},}
$$

Where $\mathrm{Y}_{\mathrm{ijk}}=$ The observation, $\mu=$ General mean, $\mathrm{T}_{\mathrm{i}}=$ Fixed effect of $\mathrm{i}^{\text {th }}$ probiotic treatments, $i=1,2, \ldots .6, F_{j}=$ Fixed effect of $j^{\text {th }}$ feeding duration time $(j=15,30$ and 45 days), $\mathrm{TFD}_{\mathrm{ij}}=$ the fixed effect of interaction between probiotic treatments and feeding duration time, and $\mathrm{e}_{\mathrm{ijk}}=$ Error of the model. Significance of the differences in the results was tested by Duncan's New Multiple Range Test (Duncan, 1955).

\section{RESULTS AND DISCUSSION}

\section{Blood plasma lipids: \\ Total cholesterol:}

Rats fed on non-probiotic cream+basal ration had significantly $(\mathrm{P}<0.001)$ the highest total cholesterol content as compared with those fed on basal ration at different feeding duration studied (Table 1). It is well noticed that as the feeding duration period increased from 15 to 30 and up to 45 days total cholesterol substantially increased in blood plasma rats. Such increase varies according to the type of the probiotic strain inclusion in the prepared cream and the non probiotic cream as well. The respective increase in total cholesterol content through feeding duration from $15-45$ days period was $8.1,11.4,15.8,20.4 \%$ for $L$. casei; mixture of L. acidophilus + B. Bifidum + L. casei (1:1:1); B. Bifidum; L. acidophilus cream and $33.2 \%$ for the non probiotic cream with significant differences (Table1).

After 45 days of feeding, results revealed that cream supplemented with $L$. casei was the best in terms of reducing total cholesterol by $28.41 \%$, followed by 25.73 , 21.60 and $19.60 \%$ for mixture of three strains, B. bifidum and L. acidophilus, respectively compared to non probiotic cream, with significant differences. Such results agreed with those of Thompson and Rochelle (1982), Dora and Gibson (2000) and Zommara et al. (2006). 
Table 1. Effect of probiotic bacteria during different feeding durations on blood plasma lipids

\begin{tabular}{|c|c|c|c|c|c|c|}
\hline Treatments & $\begin{array}{c}\text { Feeding } \\
\text { duration } \\
\text { (days) }\end{array}$ & $\begin{array}{c}\text { Total } \\
\text { Cholesterol }\end{array}$ & HDL & LDL & $\begin{array}{l}\text { Total } \\
\text { lipids }\end{array}$ & $\begin{array}{c}\text { Tri- } \\
\text { glycerides }\end{array}$ \\
\hline & & \multicolumn{5}{|c|}{ 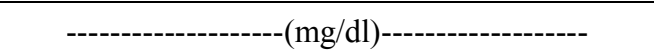 } \\
\hline \multirow[t]{3}{*}{ Basal ration (BR) } & 15 & $127.68^{1}$ & $50.14^{\mathrm{g}}$ & $41.84^{\text {de }}$ & $93.24^{1}$ & $92.82^{\mathrm{jk}}$ \\
\hline & 30 & $129.84^{\mathrm{kl}}$ & $51.52^{\mathrm{g}}$ & $41.72^{\mathrm{de}}$ & $94.46^{\mathbf{k l}}$ & $93.26^{\mathrm{jk}}$ \\
\hline & 45 & $130.60^{\mathbf{j k}}$ & $51.74^{\mathrm{g}}$ & $42.38^{\text {de }}$ & $95.22^{\mathrm{kl}}$ & $95.42^{\mathrm{hi}}$ \\
\hline \multirow[t]{3}{*}{$\mathrm{BR}+$ cream } & 15 & $150.20^{\mathrm{e}}$ & $45.66^{\mathrm{h}}$ & $46.22^{\mathrm{c}}$ & $100.40^{\text {hi }}$ & $111.22^{\mathrm{d}}$ \\
\hline & 30 & $183.22^{\mathrm{b}}$ & $46.02^{h}$ & $50.24^{\mathrm{b}}$ & $136.86^{\mathbf{b}}$ & $135.40^{\mathbf{b}}$ \\
\hline & 45 & $199.80^{\mathrm{a}}$ & $47.06^{\mathrm{h}}$ & $53.74^{\mathrm{a}}$ & $185.22^{\mathrm{a}}$ & $141.24^{\mathrm{a}}$ \\
\hline \multirow[t]{3}{*}{$\mathrm{BR}+$ L.acidophilus cream } & 15 & $133.42^{\mathrm{ij}}$ & $55.34^{\mathrm{ef}}$ & $39.20^{\text {ghi }}$ & $98.20^{\mathrm{ij}}$ & $95.60^{\mathrm{hi}}$ \\
\hline & 30 & $144.48^{\mathrm{f}}$ & $59.20^{\mathbf{b c}}$ & $40.80^{\text {efg }}$ & $106.36^{\mathrm{g}}$ & $100.84^{\mathrm{f}}$ \\
\hline & 45 & $160.64^{\mathrm{c}}$ & $56.38^{\text {def }}$ & $43.24^{\mathrm{d}}$ & $130.62^{\mathrm{c}}$ & $118.46^{\mathrm{c}}$ \\
\hline \multirow[t]{3}{*}{$\mathrm{BR}+$ B.bifidum cream } & 15 & $135.20^{\mathbf{h i}}$ & $54.12^{\mathrm{f}}$ & $38.94^{\mathrm{hi}}$ & $99.36^{\mathbf{i}}$ & $94.00^{\mathrm{ij}}$ \\
\hline & 30 & $142.58^{\mathrm{f}}$ & $57.00^{\text {cde }}$ & $38.62^{\mathrm{hi}}$ & $111.40^{\mathrm{e}}$ & $98.40^{\mathrm{g}}$ \\
\hline & 45 & $156.64^{\mathrm{d}}$ & $59.20^{\mathbf{b c}}$ & $43.00^{\mathrm{d}}$ & $137.28^{\mathbf{b}}$ & $117.22^{\mathrm{c}}$ \\
\hline \multirow[t]{3}{*}{$\mathrm{BR}+$ L.casei cream } & 15 & $132.50^{\mathrm{ijk}}$ & $58.20^{\text {bed }}$ & $37.76^{\mathbf{i}}$ & $95.94^{\mathbf{j k}}$ & $90.06^{1}$ \\
\hline & 30 & $136.62^{\mathrm{h}}$ & $62.24^{\mathrm{a}}$ & $39.60^{\text {fgh }}$ & $102.52^{h}$ & $94.18^{\mathrm{ij}}$ \\
\hline & 45 & $143.04^{\mathrm{f}}$ & $63.80^{\mathrm{a}}$ & $39.74^{\text {fgh }}$ & $111.16^{\mathrm{e}}$ & $99.60^{\mathrm{fg}}$ \\
\hline \multirow[t]{3}{*}{ BR+Mixture of 3 strains } & 15 & $133.20^{\mathrm{ij}}$ & $54.50^{\mathrm{f}}$ & $39.18^{\text {ghi }}$ & $96.20^{\mathbf{j k}}$ & $91.80^{\mathrm{k}}$ \\
\hline & 30 & $139.62^{\mathrm{g}}$ & $64.40^{\mathrm{a}}$ & $39.34^{\text {ghi }}$ & $108.64^{f}$ & $96.36^{\mathrm{h}}$ \\
\hline & 45 & $148.40^{\mathrm{e}}$ & $59.64^{\mathrm{b}}$ & $41.10^{\text {ef }}$ & $119.72^{d}$ & $107.46^{\mathrm{e}}$ \\
\hline Stander error & & \pm 0.9 & \pm 0.7 & \pm 0.5 & \pm 0.8 & \pm 0.5 \\
\hline \multicolumn{7}{|l|}{ Significance } \\
\hline Treatments & & $* * *$ & $* * *$ & $* * *$ & $* * *$ & $* * *$ \\
\hline Feeding duration & & $* * *$ & $* * *$ & $* * *$ & $* * *$ & $* * *$ \\
\hline Interaction & & $* * *$ & $* * *$ & $* * *$ & $* * *$ & $* * *$ \\
\hline
\end{tabular}

Mixture of 3 strains $=$ L.acifophilus + B.bifidum + L.casei $(1: 1: 1)$

a,b,c,d Values with different superscripts in the same column differ significantly $(\mathrm{P}<0.05)$.

${ }^{* * *} \mathrm{P}<0.001$.

After 45 days of feeding, results revealed that cream supplemented with $L$. casei was the best in terms of reducing total cholesterol by $28.41 \%$, followed by 25.73 , 21.60 and $19.60 \%$ for mixture of three strains, B. bifidum and L. acidophilus, respectively compared to non probiotic cream, with significant differences. Such results agreed with those of Thompson and Rochelle (1982), Dora and Gibson (2000) and Zommara et al. (2006).

The reason for the observed hypocholesterolemic effect is proposed to be related to the applied bacterial culture in the prepared probiotic cream. Such probiotic bacterial grow in the intestine, making cholesterol unavailable for absorption into the circulatory system. In addition, supplemented cream with probiotic bacteria is more likely seemed to be the practical way for reducing plasma cholesterol. The probiotic bacteria may alter serum cholesterol by two proposed mechanisms: directly binding dietary cholesterol into the small intestine before cholesterol can be absorbed into the body (Gilliland et al., 1985 and Hosono and Tono-oka, 1995) and de-conjugating bile acids to produce free bile acids (Gopal et al., 1996). 


\section{High-density lipoprotein (HDL) cholesterol:}

The HDL cholesterol results showed that any of the prepared probiotic cream exerted significantly higher cont of HDL cholesterol than the non-probiotic cream with variable magnitudes (Table 1). In such probiotic cream, after the first feeding duration periods (15 days) L. casei cream supplementation was effective in enhancing HDL cholesterol content values in blood plasma of the fed-rats, whereas the mixture of the three strains-cream $L$. acifophilus $+B$. bifidum $+L$. casei improved HDL cholesterol content after the second feeding duration (30 days).

After the $3^{\text {rd }}$ feeding duration periods (45-days), cream supplemented with $L$. casei recorded the better HDL cholesterol values (35.57\%), followed by 26.73, 25.80, $19.81 \%$ for mixture of three strains (1:1:1), B. bifidum and L. acidophilus, respectively compared with non-probiotic cream (Table 1). These results indicate the superiority of $L$. casei cream among the other prepared probiotic cream. The obtained results showed that HDL cholesterol content may control lipid metabolism by removing free cholesterol from the peripheral cell, esterifying by removing it in the neutral lipid core or by increase rate of triglyceride catabolism. The HDL cholesterol may inhibit the uptake and degradation of LDL cholesterol competitively and the LDL cholesterol receptor mediated pathway (Tietz, 1986).

\section{Low-density lipoprotein (LDL) cholesterol:}

It is clear from (Table 1) that non-probiotic cream induced higher LDL cholesterol values as compared with the basal ration. After 15 day of feeding, probiotic supplemented cream reduced the LDL cholesterol content compared to the non-probiotic cream in a descending order as follow: L. casei probiotic cream, $B$. bifidum cream, mixture of three strains (L. acifophilus $+B$. bifidum + L. casei) cream then $L$. acidophilus with non-significant differences. Over the used probiotic bacteria, feeding intervals caused significant effect on the serum LDL cholesterol in blood of the fed-rats. The longest feeding duration (15-45 days) was significant in its effect on LDL formation by $16.3 \%$ in non-probiotic cream group compared with $10.3,10.4$, 5.22 and $4.9 \%$ for the probiotic cream supplemented with L. acidophilus., $B$. bifidum., L. casei, and their mix-cream, respectively.

Such results clarify the impact of probiotic bacteria in decreasing the harmful LDL cholesterol in some of the dairy product as cream. The reduction of LDL cholesterol in rat plasma may be due to the conversion of saturated fatty acids to unsaturated fatty acids by the action of probiotic bacteria. Delzenne and Kok (2001) reported the various factors. A possible mechanic involves the alteration of lipid metabolism by short-chain fatty acids propionate was reported to inhibit fatty acid synthetic in vitro, and acetate in a lipogenic substrate. The obtained result was comparable to those obtained by Keim et al. (1981), Agerholm et al. (2000), Usman and Hosono (2000) and Zommara et al .(2006).

\section{Total lipids:}

Data in Table (1) represent the effect of the applied probiotic treatments on total lipids of the fed-rats. Plasma total lipids contents of the blood plasma rats were significantly affected by cream supplemented probiotic bacteria and the feeding intervals. Regarding the impact of the prepared rations, the highest total lipids values were noticed in the non-probiotic supplemented cream group compared with the 
basal ration at the studied different feeding durations, with significant differences. In this respect supplemented cream with probiotic bacteria proved to be a successful procedure as a source of energy for different metabolic processes where the body may need triglyceride as a source of energy leading to decrease total lipids concentration Gilliland et al. (1985). In spit of probiotic treatments, there was substantial significant increase in total lipids content in feeding duration time (Table 1).

It is worth noting that total lipids varied among the applied probiotic bacteria and their feeding intervals with interaction significant differences (Table 1). No significant differences in total lipids were detected for the plain basal ration along the feeding periods. However, the highest total lipids content $(185.22 \mathrm{mg} / \mathrm{dl})$ was cumulated with $100.40 \mathrm{mg} / \mathrm{dl}$ in rats blood plasma fed on basal ration with non probiotic cream. Among the applied 4 probiotic cream supplementation, it is clear the less increase in total lipids was noticed for L. casei $(15.9 \%)$ then the mixture of prebiotic (L.casei+b.bifidum +l.acidophilus) group (24.4\%) in an almost even amount during the two feeding intervals 15:30 and 30:45 days. Whereas L. acidophilus and B. bifidum cause lower reduction which was about 33 and $38 \%$, respectively during the whole duration period ( 45 days), while the relatively higher increase of total lipids occurred in the latest duration period (from 30 to 45 days) than the earlier duration (15-30 days). This obtained result indicate that the activities of the tested probiotic bacteria cream varied among each others and during the feeding intervals in their impact on total lipids contents in rat blood plasma. Since probiotic cream decreased the plasmalipids contents, a source of energy for different metabolic processes, the body of rats may need Triglycerides as a source of energy leading to a decrease in its concentration (Gilliand et al., 1985).

\section{Triglycerides:}

Triglycerides content in blood plasma rats was significantly $(\mathrm{P}<0.001)$ affected by probiotic bacteria supplementation, feeding duration time and their interaction (Table 1). Upon comparing triglycerides content of the basic ration $(92.82-95.42 \mathrm{mg} / \mathrm{dl})$ and the basal ration with non probiotic cream $(111.22-141.24 \mathrm{mg} / \mathrm{dl})$, it was clear that the later treatment was higher in triglycerides content than the previous one (Table 1).

Triglycerides contents varied significantly according to the probiotic bacteria used with the basal ration of the prepared probiotic-cream. Triglycerides were ranged from $90.06-99.60,91.80-107.46,94.00-117.22$ and $95.60-118.46 \mathrm{mg} / \mathrm{dl}$ for $L$. casei, mixture of three strains (L. casei $+B$. bifidum + L. acidophilus), B. bifidum and L. acidophilus probiotic cream, respectively with significant differences (Table 1).

No differences were observed in triglycerides content for the feeding duration periods of the basal ration of rats. However, feeding intervals of the prepared probiotic cream patches showed substantial significant increase in the triglycerides content as the feeding duration period increased from 15 to 30 and up to 45 days with variable magnitudes according to the applied probiotic bacteria. Relatively higher triglycerides formation was noticed for second feeding period (30 to 45 days) for $B$. bifidum, L.acidophilus and the three mix strains (L.casei+B.bifidum+L.acidophilus) cream. Whereas, the non probiotic cream was more active in increasing triglycerides at the early feeding period of 30 days and equal reduction was noticed during each of the two feeding intervals for $L$. casei probiotic cream (Table 1). Upon extended 
feeding period for 45 days, triglycerides were increased by 48.02, 24.15, 22.85, 12.62 and $4.38 \%$ in plasma rats fed the non probiotic cream, L. acidophilus, B. bifidum, the mix three strain cream and $L$. casei cream, respectively compared with those fed basal ration (Table1). Such result proved the superiority of $L$. casei $>$ mixture of strains $>B$. bifidum $>L$. acidophilus cream. These results suggested that probiotic bacterial cream could be administrated to reduce plasma triglyceride level in rats blood. Such effect was more pronounced in the rats fed L. casei and mixture of the three strains bacteria. The obtained results were in accordance with those of Jones et al. (1985) and Usman \& Hosono (1999).

\section{Microbiological analysis:}

Results in table (2) clarified that both the prepared probiotic cream and non probiotic cream did not show any noticeable increase in probiotic bacteria and total count respectively during along the storage periods at $-18^{\circ} \mathrm{C}$ during 45 -day

Table 2. Survival of lactic acid bacteria $\left(10^{7}\right)$ in probiotic cream and total bacterial count $\left(10^{2}\right)$ in the non- probiotic cream during storage period at $-18 \pm 2{ }^{\circ} \mathrm{C}$

\begin{tabular}{lcccc}
\hline \multirow{2}{*}{ Treatments } & \multicolumn{4}{c}{ Storage periods (days) } \\
\cline { 2 - 5 } & Fresh & 15 & 30 & 45 \\
\hline L. acidoplilus & 33.40 & 33.00 & 33.25 & 35.00 \\
B. bifidum & 33.50 & 35.00 & 32.33 & 31.95 \\
L. casei & 47.5 & 48.35 & 49.75 & 50.75 \\
Mixture of strains (1:1:1): & & & & \\
$\quad$ L. acidoplilus & 27.50 & 27.75 & 28.85 & 29.75 \\
$\quad$ B. bifidum & 27.80 & 28.70 & 29.75 & 30.75 \\
$\quad$ L. casei & 32.20 & 32.75 & 33.50 & 34.15 \\
$\quad \begin{array}{l}\text { Total count of Non-probiotics } \\
\text { cream }\end{array}$ & 11.25 & 11.30 & 12.75 & 13.00 \\
\hline
\end{tabular}

The count of coliforms and staphylococci $(\log$. cfu/ml) in rats feces were significantly $(\mathrm{P}<0.001)$ affected by inclusion probiotic bacteria cream, feeding duration time and their interaction (Table 3).

Feeding basal ration (control) was increased the count of Coliforms and staphylococci significantly compared to rats fed basal ration with non-probiotic cream during the whole feeding durations. An opposite trend was recorded in rats feces fed basal ration with probiotic cream, with significantly reduced counts. Results also clarified that $L$. casei cream showed the highest reduction for Coliforms and Staphylocci bacteria, followed by the supplemented cream with three strain mixtures of $L$. casei $+B$. bifidum $+L$. acidophilus $(1: 1: 1)$ compared to supplemental B. bifidum and L. acidophilus groups.

Similarly, Loing and Shah (2006) mentioned that lactic acid is the major end product of lactate producing lactobacilli. Also, most inhibition of Coliforms and Staphylocci have contributed in decreasing the intestinal $\mathrm{pH}$ (Swanson et al., 2002). Meanwhile, the positive influence on the pathogenic population may be supported by the higher concentration of lactic acid in cecum of rats fed on probiotic bacteria as compared with the control diet. 
Table 3. Effect of probiotic bacteria during different feeding durations on Coliforms and Staphylococci count $(\log$. cfu/ml) in rats feces

\begin{tabular}{|c|c|c|c|}
\hline Treatments & $\begin{array}{l}\text { Feeding } \\
\text { duration } \\
\text { (days) }\end{array}$ & Coliforms & Staphylococci \\
\hline \multirow[t]{3}{*}{ Basal ration (BR) } & 15 & $6.041^{\mathrm{abc}}$ & $5.939^{\text {abc }}$ \\
\hline & 30 & $6.124^{\mathrm{ab}}$ & $6.023^{\mathrm{ab}}$ \\
\hline & 45 & $6.275^{\mathrm{a}}$ & $6.109^{\mathrm{a}}$ \\
\hline \multirow[t]{3}{*}{$\mathrm{BR}+$ cream } & 15 & $5.884^{\text {bcd }}$ & $6.023^{\mathrm{ab}}$ \\
\hline & 30 & $6.069^{\mathrm{abc}}$ & $6.027^{\mathrm{ab}}$ \\
\hline & 45 & $6.203^{\mathrm{a}}$ & $6.050^{\mathrm{a}}$ \\
\hline \multirow[t]{3}{*}{$\mathrm{BR}+L$. acidophilus cream } & 15 & $4.724^{\text {ef }}$ & $5.161^{\mathrm{e}}$ \\
\hline & 30 & $4.602^{\text {efgh }}$ & $4.924^{\mathrm{f}}$ \\
\hline & 45 & $4.300^{\mathrm{ij}}$ & $4.577^{\mathrm{gh}}$ \\
\hline \multirow[t]{3}{*}{$\mathrm{BR}+B$. bifidum cream } & 15 & $4.813^{\mathrm{e}}$ & $5.250^{\mathrm{e}}$ \\
\hline & 30 & $4.650^{\text {efg }}$ & $4.720^{\mathrm{fg}}$ \\
\hline & 45 & $4.360^{\mathrm{hij}}$ & $4.380^{\mathrm{hi}}$ \\
\hline \multirow[t]{3}{*}{$\mathrm{BR}+$ L.casei cream } & 15 & $4.423^{\text {ghij }}$ & $5.146^{\mathrm{e}}$ \\
\hline & 30 & $4.040^{\mathrm{k}}$ & $4.350^{\mathrm{i}}$ \\
\hline & 45 & $3.778^{1}$ & $4.114^{\mathbf{j}}$ \\
\hline \multirow[t]{3}{*}{$\mathrm{BR}+$ Mixture of three strains } & 15 & $4.498^{\text {fghi }}$ & $5.243^{\mathrm{e}}$ \\
\hline & 30 & $4.423^{\text {ghij }}$ & $4.591^{\mathrm{gh}}$ \\
\hline & 45 & $4.170^{\mathrm{jk}}$ & $4.200^{\mathrm{ij}}$ \\
\hline Stander error & & \pm 0.081 & \pm 0.073 \\
\hline \multicolumn{4}{|l|}{ Significance } \\
\hline Treatments & & $* * *$ & $* * *$ \\
\hline Feeding duration & & $* * *$ & $* * *$ \\
\hline Interaction & & $* * *$ & $* * *$ \\
\hline
\end{tabular}

\section{CONCLUSIONS}

It could be concluded that rats fed on probiotic cream induced significant reduction in their plasma lipids: Total cholesterol content, L.D.L. cholesterol level, total lipids and triglycerides content and an increase in H.D.L. cholesterol level, and decreasing population of coliforms and staphylococci bacteria in rats feces. So, health beneficial effect could be achieved from using probiotic dietary cream. Where $L$. casei and Mixture of three strains (L. casei $+B$. bifidum $+L$. acidophilus) were superior in such beneficial effect followed by B. bifidum and L. acidophilus

\section{REFERENCES}

Agerholm, L., A. Raben, N. Haulrik, A.S. Hansen, M.Manders and A. Astrup, 2000. Effect of 8 week intake of probiotic milk products on risk factors for cardiovascular diseases. European Journal of Clinical Nutrition. 54: 289-297. 
APHA, 1992. Standard Methods for the Examination of Dairy Product. American Publ. Health. Assoc. Inc. $16^{\text {th }}$ Ed., Washington D. C.

Baird-Parker, A.C., 1962. An improved digenetic and selective medium for isolating coagulase positive staphylococci. J. Appl. Bact. 25 (1):12-19.

Coakley, M., R.P. Ross, M. Nordgren, G. Fitzgerald, R. Denver and C. Stanton, 2003. Conjugated linoleic acid and bio synthesis by human, olerived $\mathrm{Bi}$ fidobacterium species. J. Apple. Microbiol. 94(1): 138-145.

Dave, R.I and N.P. Shah, 1996. Evaluation of media for selective enumeration of S.thermophilus,L.delbrukii ssp.Bulgaricus,L.acidophilus, and Bididobacteria. J. Dairy Sci., 79 (9):1529-1536.

Delzenne, N.M. and N. Kok, 2001. Effects of fructans-type prebiotic on lipid metabolism. Am. J. Clin. Nutr. 73:456S-458S.

Deman, J.M., 1964. The free and ester cholesterol content of mild and dairy products. Z. Ernaehrungswiss, 5: 1.

Duncan, D.B., 1955. Multiple range and multiple F. test. Biometrics, 11: 1-42.

Famularo, G., C. De Simon, V. Pandey, A.R. Sahu, G. Mimisola, 2005. Probiotic lactobacilli; an innovative tool to correct the malabsorption syndrome of vegetarians?. Med Hypotheses, 65 (6):1132-1135.

Fooks, L.J., R. Fuller and B.R. Gibson, 1999. Prebiotics, probiotics and human gut microbiology. Int. Dairy J., 9: 53-61.

Gilliland, S.E., C.R. Nelson, and C. Maxwell, 1985. Assimilation of cholesterol by L.lactobacillus acidophilus. Appl. Environ. Microbiol., 33:15-18.

Gopal, A., N.P. Shah, and H. Roginski, 1996. Bile tolerance taurocholate deconjugation and cholesterol removal by Lactobacillus acidophilus and Bifidobacteriums spp. Milchwissenschaft, 51: 619-623.

Guyonnet, D., O. Chassany, P. Ducrotte, 2007. Effect of fermented milk containing Bifidobacterium animalis DN-173 010 on the health-related quality of life and symptoms in irritable bowel syndrome in adults in primary care: a multicentre, randomized, double- blind, controlled trial. Aliment. Pharmacol. There. 26 (3); 475-486.

Hitti, Miranda, 2006. Probiotics may help stressed Gut (htt://www.web md.com/content/article/121/114283.htm) web MD. Retr ieved on 2006-10-24).

Hosono, A. and T. Tono-oka, 1995. Binding of cholesterol with lactic acid bacteria cells. Milchwissenschaft 50:556-560.

Jenness, R. and S. Patton, 1959. Principles of Dairy chemistry... N.Y.: John Willey \& Sons, Inc..

Jiang, T., A. Mostafa, D.A. Savaiano, 1996. Improvement of lactose digestion by ingestion of unfermented milk containing B. longum. J. Dairy Sci. (79): 750-757.

Kailasapathy, K. and S. Rybka, 1997. L. acidophilus and Bifido bacterium spp. their therapeutic potential and survival in yoghurt. The Aus. J. of Dairy Techn., (52): 28-35.

Keim, N.L., J.A. Marlett and C.H. Amundsopn, 1981. The cholesterolemic effect of skim milk in young men consuming controlled diets. Nutr. Res. 1:429-442.

Kocian, J., 1994. Lactobacilli in the treatment of dyspepsia due to dysmicrobia various causes. Vnitr Lek., 40 (2):79-83.

Lacroix, D.E., A.M. William, P.W. Noble and A.A. john, 1973. Cholesterol, fat and protein in dairy products. J. of the American Association, (62): 275-279. 
Liong, M.T. and N.P. Shah, 2006. Effect of a Lactobacillus casei Synbiotic on Serum Lipoprotein, Intestinal Microflora and Organic Acids in Rats. American Dairy Sci., 89:1390-1399.

Marshall, R.T., 1992. Standard methods for the examination of dairy products. American Public Health Association (APHA) Washington, D.C., USA.

Nichols, Andrew W., 2007. "Probiotics and athletic performance: A systematic review. Current Sports Medicine Reports 6 (4): 269-273.

Reid G., J. Juss, M.T. Sebulsky, J.K. Mc Cormick, 2003. Potential uses of probiotics in clinical practice. Clin Microbial rev. 16:658-72.

Sanders, M.E., 2000. Considerations for use of probiotic bacteria to modulate human health. J. Nutr. 130:384S-390s.

SAS $^{\circledR}, 1996$. User's Guide: Statistics, Version 6.12 Edition. SAS inst. Inc., Cary, NC, USA.

Swanson, K.S., C.M. Griesho, E.A. Flickinger, L.L. Bauer, B.W. Wolf, J.M. Chow, K.A. Garleb, J.A. Williams and G.C. Fahey, 2002. Fructo-oligosaccharides and Lactobacillus acidophilus modify gut microbial populations, total tract nutrient digestibility and fecal protein catabolite concentrations in healthy adult dogs. J. Nutr. 132:3721-3731.

Thompson, L.U. and R. Rochelle, 1982. The effect of fermented and unfermented milks on serum cholesterol. The American Journal of Nutrition. (36): 1106.

Tietz, N.W., 1986. Text book of clinical Chemistry, W.B. Saunders company, Philadelphia, Toronto Mexico city, Rio de Janeiro, Sydney Tokyo and Hong Kong.

Usman and A. Hosono, 2000. Effect of Administration of Lactobacillus gasseri on Serum Lipids and Fecal Steroids in Hyper-cholesterolemic Rats. J. Dairy Sci., 83:1705-1711.

Vinderola, C.G. and J.A. Reinheimer, 2000. Enumeration of L.casei in the presence of L.acidophilus, bifidobacteria and lactic starter bacteria in fermented dairy products. Int. Dairy J.;10 (4): 271-275.

Whorwell, P.J., L. Altringer, J. Morel, Y. Bond, D. Charbonneau, L. O'Mahony, B. Kialy,F. Shanahun, E.M. Quigley, 2006. Efficacy of an encapsulated probiotic Bifido bacterium infantis 35624 in Women with irritable bowl syndrome (http://www.ncbi.nlm.nih.gov/entrez/query.fcgi?. Am. J. Gastroenterol, Retrieved 2007-12-02.

Zollner, N., K. Kirsch, 1962. Z. Ges. exp. Med., 135:545.

Zommara, M.A., A.M. El-Baz, M.A. Rashed and A.A. Mansour, 2007. Health promoting effects of mixed zabady and bifidobacteria fermented milks fed to rats. 
تأثير الكريمة المدعمة بالبكتريا الحيوية على ليبيدات بلازما الدم وفاء بديع السبع'، سامية ابراهيم حربى'

1 - قسم كيمياء الالبان، معهل بحوث الاتتاج الحيوانس، r - قسم ميكرييولوجيا الالبان، معهُ بحوث الانتاج الحيوانسى

تم استخدام عدد ·r فأر ذكر Albino فى هذه الدراسة، قسمت الى 7 مجاميع متساوية. تم

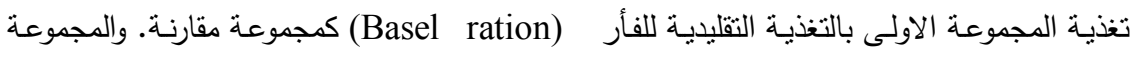

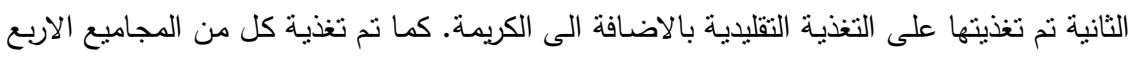

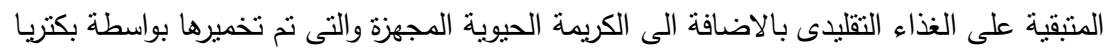

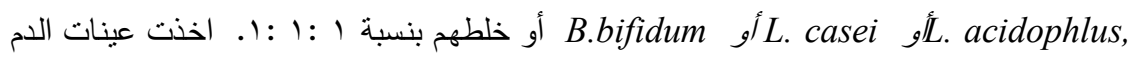

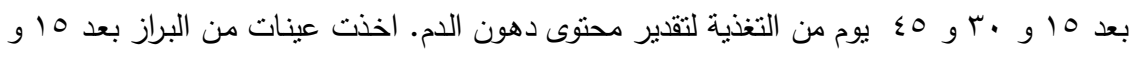
• r و 0؛ يو هو من التغذية لعمل التحليلات الميكروبيولوجية. وجد ان الكوليستيرول الكلى و الكوليستيرول المحتوى على ليبوبروتين منخفض الكثافة (LDL)

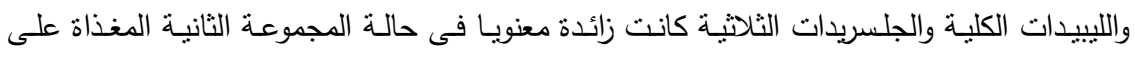

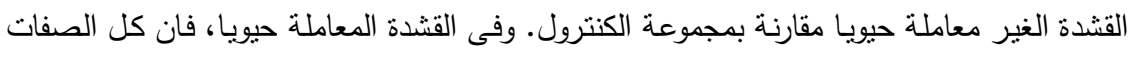

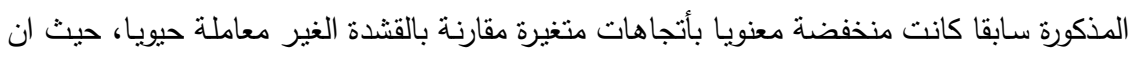
L. casei

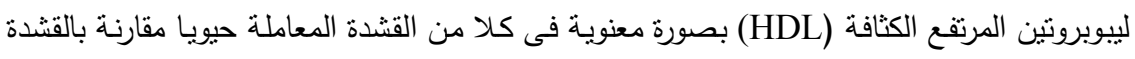

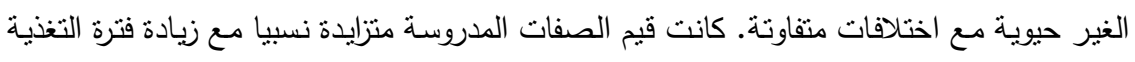

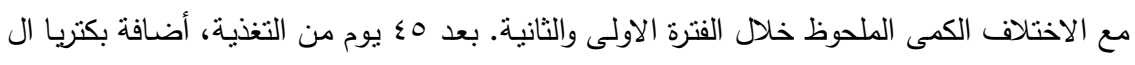

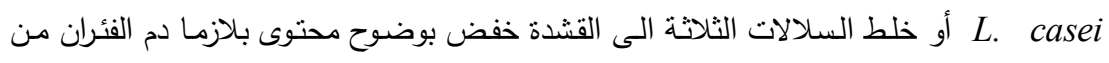

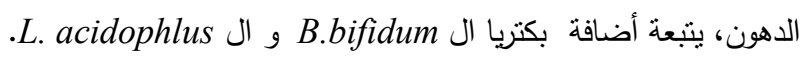

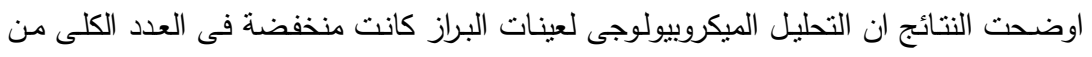
staphylococci

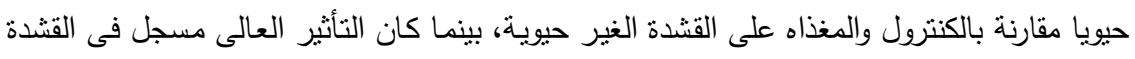

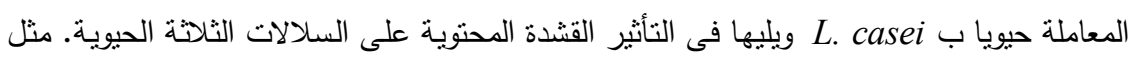

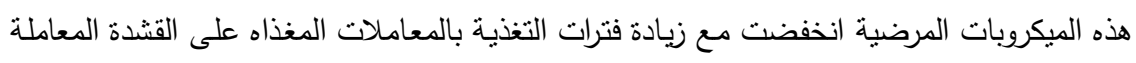

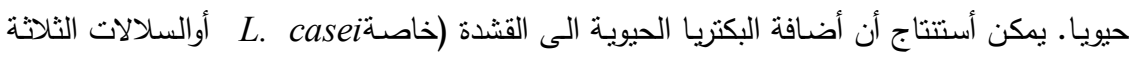




$$
\begin{aligned}
& \text { الحيوية بنسبة 1:1:1 قلل من التأثيرات الضارة الناتجة عن التغذية على القثدة فقط و تعطى تأثير } \\
& \text { صحى جيد. }
\end{aligned}
$$

